\title{
Malignant cerebral edema: an unusual neurological manifestation of systemic lupus erythematosus
}

\author{
Edema cerebral maligno: uma manifestação neurológica atípica do lúpus \\ eritematoso sistêmico
}

Marianna Pinheiro Moraes DE MORAES', Barbara TRAPP², Flávio Moura REZENDE FILHO', Victor Hugo Rocha MARUSSI,3, Orlando Graziani Povoas BARSOTTINI', José Luiz PEDROSO'

A 46-year-old woman presented with headache and decreased level of consciousness. She had systemic lupus erythematosus (SLE) with positive antibodies. Cerebrospinal fluid (CSF) pressure was $350 \mathrm{mmH}_{2} \mathrm{O}$. Brain magnetic resonance imaging (MRI) revealed white matter changes and edema. MRI angiography and vessel wall imaging ruled out vasculitis (Figure 1). Malignant cerebral edema related to SLE was diagnosed. She had complete recovery after methylprednisolone and cyclophosphamide.

Several neurological manifestations have been described in SLE, including intracranial hypertension syndrome, which is unusual ${ }^{1}$. Malignant cerebral edema is a distinct syndrome rarely observed in $\mathrm{SLE}^{2}$. Severe bloodbrain barrier disruption and vasculitis are the most likely pathophysiological mechanisms, and treatment includes immunotherapy ${ }^{2}$.

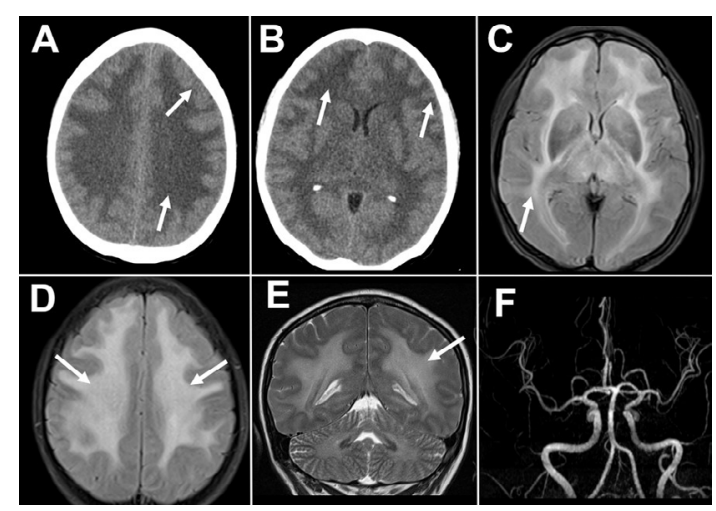

Figure 1. Brain CT scan shows cerebral edema with loss of sulci and white matter hypodensity (A and B). Axial FLAIR-weighted and coronal T2-weighted brain MRI reveal bilateral, symmetrical, and diffuse hyperintense signal in white matter, with loss of cerebral sulci, characterizing cerebral edema (C, D, and E). MRI angiography is normal (F).

\section{References}

1. Alessi H, Dutra LA, Braga Neto P, Pedroso JL, Toso FF, Kayser C, et al. Neuropsychiatric lupus in clinical practice. Arq. Neuropsiquiatr. 2016 Dec;74(12):1021-30. https://doi.org/10.1590/0004-282×20160150
2. Koffman L, Prayson R, Manno EM. Malignant cerebral edema related to systemic lupus erythematosus. J Neurol Sci. 2016 Mar;364:180. https://doi.org/10.1016/j.jns.2016.03.040

\footnotetext{
${ }^{1}$ Universidade Federal de São Paulo, Department of Neurology, São Paulo SP, Brazil.

¿2Universidade Federal de São Paulo, Neuroradiology Subdivision, Department of Imaging Diagnosis, São Paulo SP, Brazil.

${ }^{3}$ Beneficência Portuguesa de São Paulo, Department of Neuroradiology, São Paulo SP, Brazil.

Marianna Pinheiro Moraes DE MORAES (D) https://orcid.org/0000-0003-1273-9083; Barbara TRAPP (D) https://orcid.org/0000-0001-5554-6674; Flávio Moura REZENDE FILHO (ID https://orcid.org/0000-0003-4565-5898; Victor Hugo Rocha MARUSSI (DD https://orcid.org/0000-0002-0333-0342; Orlando Graziani Povoas BARSOTTINI (D) https://orcid.org/0000-0002-0107-0831; José Luiz PEDROSO (D) https://orcid.org/0000-0002-1672-8894

Correspondence: Orlando Graziani Povoas Barsottini; E-mail: orlandobarsottini@gmail.com

Conflict of interest: There is no conflict of interest to declare.

Authors' contributions: MMPM: case report project conception, organization, execution, manuscript writing of the first draft, review and critique. BT: case report project: conception, organization, execution, manuscript writing of the first draft, review and critique. FMRF: case report project: conception, organization, execution, manuscript review and critique. VHRM: case report project conception, organization, execution, manuscript review and critique. OGPB: case report project conception, organization, execution, manuscript review and critique. JLP: case report project conception, organization, execution, manuscript review and critique.

Received on May 26, 2020; Received in its final form on June 5, 2020; Accepted on June 15, 2020.
} 